\title{
Genetic parameters prediction (REML/BLUP) for morphological, physical-chemical, phytochemical, and mineral components of primocane-fruiting raspberries
}

P.M. Marchi ${ }^{1}$, I.R. Carvalho ${ }^{1}$, D. Höhn ${ }^{1}$, B. Carra $^{1}$, V.J. Szareski ${ }^{1}$, M. Dini ${ }^{1}$, M. Vizzotto ${ }^{2}$ and L.E.C. Antunes ${ }^{2}$

${ }^{1}$ Faculdade de Agronomia Eliseu Maciel, Universidade Federal de Pelotas, Capão do Leão, RS, Brasil

${ }^{2}$ Empresa Brasileira de Pesquisa Agropecuária, Estação Experimental de Fruticultura de Clima Temperado, Pelotas, RS, Brasil

Corresponding author: P.M. Marchi

E-mail: marchi.priscila.90@gmail.com

Genet. Mol. Res. 18 (2): gmr18254

Received February 04, 2019

Accepted May 17, 2019

Published May 24, 2019

DOI http://dx.doi.org/10.4238/gmr18254

ABSTRACT. Raspberry is a berry crop of great economic importance, and its cultivation has expanded worldwide. Information on the genetic parameters of raspberry for use in breeding programs is currently limited. We used Restricted Maximum Likelihood (REML) and Best Linear Unbiased Prediction (BLUP) to estimate variance components and predict genetic parameters for morphological, phytochemical, and mineral components in primocane-fruiting raspberries in southern Brazil. The experimental design was randomized blocks in a factorial scheme, with two production cycles (fall and spring) x three cultivars ('Alemãzinha', 'Heritage' and, 'Fallgold'), with eight replicates. A total of 27 traits were evaluated, out of which only the traits beginning of fruit harvest, plant height, dry mass of pruning, average fruit weight, total phenolic compounds, anthocyanins, antioxidant activity, $\mathrm{Ca}, \mathrm{Mg}, \mathrm{Cu}$, $\mathrm{Fe}, \mathrm{Mn}, \mathrm{Zn}$, and titratable acidity showed significant differences. The anthocyanins presented $87 \%$ of broad sense heritability, and this high value indicates that this trait can be improved through selection. Plant height, fruit weight, total phenolic compounds, $\mathrm{Mg}$ and $\mathrm{Fe}$ had moderate broad sense heritability $(46,58,58,51$, and $66 \%$, respectively); and the traits beginning of fruit harvest, dry mass of 
P.M. Marchi et al.

pruning, antioxidant activity, $\mathrm{Ca}, \mathrm{Cu}, \mathrm{Mn}, \mathrm{Zn}$, and titratable acidity are strongly influenced by production cycle effects. Greater genetic variance contribution in the interaction between genotypes $\times$ production cycle was observed for plant height, fruit weight, total phenolic compounds, anthocyanins, antioxidant activity, $\mathrm{Mg}$ and $\mathrm{Fe}$. The genotype 'Alemãzinha' was superior for beginning of fruit harvest, plant height, anthocyanins, titratable acidity, and several minerals. Five inheritable profiles were found; the profile IV, including plant height, fruit weight, $\mathrm{Mg}, \mathrm{Fe}$, and total phenols had moderate broad sense heritability. Only profile V, composed of anthocianins, presented high heritability.

Key words: Rubus idaeus; Plant breeding; Heritability; RELM/BLUP; Berries; Small fruits

\section{INTRODUCTION}

In recent years, a steady increase in the popularity of fruits can be noted, promoting research interest. Particularly, small fruits have caught attention, as berries are the best dietary sources of bioactive compounds (Skrovankova et al., 2015). Raspberries (Rubus idaeus) are included in this group; and the crop has shown great economic importance, evidenced by the increase of world production, which has nearly doubled over the past 20 years. This demand has prompted a necessity to continuously develop improved genotypes in terms of quality and quantity (Palonen et al., 2017).

Primocane-fruiting raspberries can produce fruit within one growing season, usually in the late summer or autumn (Pritts, 2008). This fruiting type facilitates yield increases and harvesting seasonality. However, expression of most traits in terms of genetic (G) effects, environmental $(\mathrm{E})$ influences, and interaction between genotype $\times$ production cycle or growing environment $(\mathrm{G} \times \mathrm{E})$ have not been studied in Brazil so far.

The main objectives in the breeding programs for raspberries are related to high fruit quality, morphological traits, yield, suitability for market and machine harvesting, environmental adaptation, and pest and disease tolerance or resistance (Stephens et al., 2012a; Gambardella et al., 2016; Jennings et al., 2016; Moore et al., 2016; Orzel et al., 2016). Another breeding goal is to improve the content of phytochemical compounds such as anthocyanin, phenolic compounds, and soluble solids (Milivojevic et al., 2011; Stephens et al., 2012a; Orzel et al., 2016).

The choice of parents in raspberry breeding is based on their phenotypic performance. However, knowledge of the genetic mechanism that controls the inheritance of a trait and the impact of genetic and environmental factors on their expression is essential for a successful breeding program (Akšić et al., 2011). A good procedure to estimate variance components and predict genetic parameters is through Restricted Maximum Likelihood (REML) and Best Linear Unbiased Prediction (BLUP), respectively (Carvalho et al., 2017).

We examined genetic parameters and variance components estimates prediction for morphological, phytochemical and mineral components in primocane-fruiting raspberries grown in Brazil.

\section{MATERIAL AND METHODS}

\section{Experimental design}


The experiment was carried out from Nov 2013 to Dec 2014, in Pelotas, Rio Grande do Sul, Brazil. The latitude is $31^{\circ} 46^{\prime} \mathrm{S}$, longitude $52^{\circ} 20^{\prime} \mathrm{W}$, and altitude of $60 \mathrm{~m}$. The climate is characterized by Köppen as "Cfa" - subtropical with hot summer (Alvares et al., 2014). The experimental design was randomized blocks in a factorial scheme, with two production cycles (autumn and spring) $\times$ three cultivars ('Alemãzinha' and 'Heritage', which produces red fruits; and 'Fallgold', which produces yellow fruits), with eight replicates. Five plants wide $1.0 \mathrm{~m}$ between rows and $0.5 \mathrm{~m}$ between plants composed the experimental units.

\section{Plant material}

The six-month plants were kept in eight-liter pots filled with commercial substrate $\left(\right.$ Germina plant ${ }^{\circledR}$ ). Slow-release fertilizer (Osmocote Plus ${ }^{\circledR}$ ) was added, at $5 \mathrm{~g} . \mathrm{L}^{-1}$, in the formulation 15-09-12 every 120 days. Control of insect-pests and diseases was performed preventively with chemical treatments and removal of senescent and injured leaves. The first pruning was performed during plant dormancy after the autumn development cycle (Aug 2014). Stems were reduced to the height of subapical buds (10 to $20 \mathrm{~cm}$ ). At the end of the spring cycle, a second pruning was performed (Dec 2014).

\section{Measurement of vegetative and productive parameters}

The measured traits were: dry mass of pruning (DM), drying it in a forced ventilation oven at $65^{\circ} \mathrm{C}$ until constant mass, followed by weighing on a digital scale, results expressed in grams; beginning of flowering $(\mathrm{BF})$ and fruit harvest $(\mathrm{BH})$, considered from the transplant, in days; average plant height $(\mathrm{PH})$, in $\mathrm{cm}$; average stem diameter (SD), in $\mathrm{mm}$; plant leaf area (PLA), measured after each productive cycle with a LI-3100C Area Meter ${ }^{\circledR}$, in $\mathrm{cm}^{2}$ plant $^{-1}$; average fruits production (FP), determined by the ratio between mass of fruits harvested in each experimental unit and number of plants, in $\mathrm{g} \mathrm{plant}^{-1}$; average fruits number (FN), verified by the ratio between total number of fruits harvested and number of plants contained in the plot, in fruits plant ${ }^{-1}$; average fruit weight $(\mathrm{FW})$, obtained by the ratio between production and number of fruits harvested, in g; fruit size, measured through the longitudinal (FLD) and transversal (FTD) diameter of fruits, in $\mathrm{mm}$, in which 20 fruits of each experimental unit were sampled; and harvesting period (HP), accessed by summing the duration of both harvesting cycles, expressed in days.

\section{Measurement of fruit physical-chemical parameters}

Physical-chemical evaluations were performed on fresh fruits and the traits assessed were soluble solids (SS), determined by a refractometer in ${ }^{\circ} \mathrm{Brix}$; hydrogenionic potential $(\mathrm{pH})$, in a digital $\mathrm{pH}$ meter; titratable acidity (TA), by potentiometric method, in a digital $\mathrm{pH}$ meter, results in percentage of citric acid; and the ratio of soluble solids and titratable acidity (SS/TA ratio).

To determine phytochemical components, fruits were stored in a freezer and evaluated at the end of harvest. Anthocyanins (AN) were quantified by the methodology adapted from Fuleki and Francis (1986), expressed in mg of equivalent cyaniding-3-glucoside per 100g of sample. Antioxidant activity (AA), was determined by Brand-Williams et al. (1995), using the stable radical 2,2-difenil-1-picrihidrazil (DPPH), expressed in $\mathrm{mg}$ of equivalent trolox per $100 \mathrm{~g}$ of sample. Total phenolic compounds (TP), were determined by the method adapted from Swain and Hillis (1959), with results expressed in $\mathrm{mg}$ of chlorogenic acid per 100g of sample. The fruit micronutrients $(\mathrm{Cu}, \mathrm{Fe}, \mathrm{Mn}$ and $\mathrm{Zn})$ and macronutrients $(\mathrm{Ca}, \mathrm{Mg}, \mathrm{K}, \mathrm{P})$ determinations were 
P.M. Marchi et al.

measured by atomic absorbance, according to the methodology adapted from Tedesco et al. (1995).

\section{Statistical analysis}

The data were subjected to the Shapiro-Wilk normality test, and to Bartlett for variance homogeneity. Subsequently, the Deviance analysis was performed $(\mathrm{P}<0.05)$ by chi-square test $\left(X^{2}\right)$ to identify the traits with variance components significant (Spilke et al., 2005). Variance components and genetic parameters (REML) were estimated using the model $y=X r+Z g+W i$ $+e$, in which $y$ : correspond to data vector; $r$ : to replicates (fix effects); $g$ : to the genotypic (random effects); $i$ : to the genotypes $\times$ production cycle interaction effects; and $e$ : to the error (random effects).

The parameters estimated were genotypic variance $\left(\sigma^{2} \mathrm{~g}\right)$; variance of the interaction of genotype $\times$ production cycle $\left(\sigma^{2}\right.$ int $)$; residual variance $\left(\sigma^{2} \mathrm{e}\right)$; phenotypic variance $\left(\sigma^{2} \mathrm{p}\right)$; broad sense heritability for total genotypic effects $\left(\hat{\mathrm{H}}^{2} \mathrm{~g}\right)$; heritability of genotypes mean $\left(\hat{\mathrm{H}}^{2} \mathrm{mg}\right)$; accuracy for genotype selection $(\hat{\mathrm{r} g} \hat{g})$; coefficient of determination of the interaction effects of genotypes $\times$ production cycle $\left(\mathrm{C}^{2} \mathrm{int}\right)$; genotypic correlation between production cycles performance $(\hat{\mathrm{rgc}})$; genotypic variation coefficient $(\mathrm{CVg} \%)$; residual variation coefficient $(\mathrm{CVe} \%)$; and overall mean (OM).

The Linear Unbiased Prediction (BLUP) were determined to rank the genotypes (R), to evidence predicted additive genetic value $(\mathrm{U}+\mathrm{G})$; the predicted additive genetic effects of the interaction of genotype $\times$ production cycle $(U+G+G E M)$; percentage of genetic gain with selection (Gain\%); and the new mean predicted (NM). The analyses were performed using the Selegen statistical software (Resende, 2007).

The broad sense heritability $\left(\mathrm{H}^{2}\right)$ magnitude estimated for each trait was submitted to a multivariate analysis by the average Euclidean distance, with the purpose of forming multivariate genetic profiles (Carvalho, 2018) through Unweighted Pair Group Method with Arithmetic Mean (UPGMA). A dendrogram with the distances was developed, and the profiles were classified according to the average distance between broad sense heritability values. The analyses were performed using the Genes software (Cruz, 2013).

\section{RESULTS}

\section{Variance components and genetic parameters}

The Deviance or Likihood ratio test (LRT) analysis evidenced significant differences for the chi-square $\left(X^{2}\right)$ test at $5 \%$ of probability for the traits beginning of fruit harvest $(\mathrm{BH})$, plant height $(\mathrm{PH})$, dry mass of pruning (DM), average fruit weight $(\mathrm{FW})$, total phenolic compounds (TP), anthocyanins (AN), antioxidant activity (AA), Calcium (Ca), Magnesium (Mg), Copper $(\mathrm{Cu})$, Iron $(\mathrm{Fe})$, Manganese $(\mathrm{Mn})$, Zinc $(\mathrm{Zn})$, and titratable acidity (AT). These results indicated that genetic components and genetic parameters obtained are consistent and reliable.

The phenotypic magnitude $\left(\sigma^{2} p\right)$ of a trait is attributed to genetic $\left(\sigma^{2} g\right)$, environmental $\left(\sigma^{2} e\right)$, and to the interaction of genotype $\times$ production cycle $\left(\sigma^{2}\right.$ int $)$ effects. Therefore, the variance components obtained through Maximum Restrict Likelihood showed that the traits $\mathrm{PH}$, FW, TP, AN, Mg, and Fe are determined by genetic effects at a moderate to high level (46, 60, $58,87,51$, and $66 \%$, respectively) (Table 1 ). In contrast, the traits $\mathrm{BH}, \mathrm{DM}, \mathrm{AA}, \mathrm{Ca}, \mathrm{Cu}, \mathrm{Mn}, \mathrm{Zn}$ and TA revealed less than $35 \%$ of the phenotypic variance $\left(\sigma^{2} \mathrm{p}\right)$ due to genetic effects $\left(\sigma^{2} \mathrm{~g}\right)$.

The largest relative contribution of the variation of the interaction of genotype $x$ production cycle $\left(\sigma^{2}\right.$ int) was verified for the fruit mineral contents $\mathrm{Ca}, \mathrm{Cu}$, and $\mathrm{Mn}$, with 57,61 
Genetic prediction of raspberry traits

and $83 \%$, respectively. The traits $\mathrm{BH}, \mathrm{DM}, \mathrm{TA}$, and $\mathrm{Zn}$ had $35,18,22$, and $28 \%$ of the variation due to the interaction effects $\left(\sigma^{2}\right.$ int $)$, respectively; and the other traits $(\mathrm{PH}, \mathrm{FW}, \mathrm{TP}, \mathrm{AN}, \mathrm{AA} \mathrm{Mg}$ and $\mathrm{Fe}$ ) presented less than $3 \%$ of interaction effects ( $\sigma^{2}$ int).

Among the variance components, the genotypic variances $\left(\sigma^{2} g\right)$ were higher than residual variances $\left(\sigma^{2} \mathrm{e}\right)$ for the traits $\mathrm{FW}, \mathrm{TP}, \mathrm{AN}$, and $\mathrm{Fe}$; the trait $\mathrm{AN}$ stands out with less than $20 \%$ of its phenotypic variance $\left(\sigma^{2} p\right)$ due to residual effects $\left(\sigma^{2} \mathrm{e}\right)$ (Table 1$)$.

Table 1. Variance components and genetic parameters (REML) for the traits beginning of fruit harvest $(\mathrm{BH})$; plant height $(\mathrm{PH})$; dry mass of pruning $(\mathrm{DM})$; average fruit weight $(\mathrm{FW})$; total phenolic compounds (TP); anthocyanins (AN); antioxidant activity (AA); $\mathrm{Ca} ; \mathrm{Mg} ; \mathrm{Cu} ; \mathrm{Fe} ; \mathrm{Mn} ; \mathrm{Zn}$; and titratable acidity (TA), measured in three raspberry cultivars during the production cycles of autumn and spring, in Rio Grande do Sul state, Brazil.

\begin{tabular}{|c|c|c|c|c|c|c|c|}
\hline \multirow[b]{2}{*}{ REML } & \multicolumn{7}{|c|}{ Trait } \\
\hline & $\begin{array}{c}\mathrm{BH} \\
\text { (days) }\end{array}$ & $\begin{array}{l}\mathrm{PH} \\
(\mathrm{cm})\end{array}$ & $\begin{array}{c}\text { DM } \\
(\text { g.plant } \\
\end{array}$ & $\begin{array}{l}\text { FW } \\
(\mathrm{g})\end{array}$ & $\mathrm{TP}^{1}$ & $\mathrm{AN}^{2}$ & $\mathrm{AA}^{3}$ \\
\hline Deviance $\left(\right.$ LRT) ${ }^{4}$ & 12.28 & 14.33 & 8.74 & 21.10 & 21.32 & 58.37 & 7.97 \\
\hline$\sigma^{2} g$ & 4.18 & 63.54 & 6.19 & 0.06 & 1434.58 & 6245.53 & 174526.42 \\
\hline$\sigma^{2} i n t$ & 12.34 & 0.23 & 5.51 & 0.00 & 3.30 & 84.00 & 10322.18 \\
\hline$\sigma^{2} e$ & 18.28 & 74.83 & 18.87 & 0.04 & 1050.24 & 823.39 & 381289.12 \\
\hline$\sigma^{2} p$ & 34.81 & 138.60 & 30.57 & 0.10 & 2488.12 & 7152.92 & 566137.73 \\
\hline$\hat{H}^{2} g$ & 0.12 & 0.46 & 0.20 & 0.57 & 0.58 & 0.87 & 0.31 \\
\hline$\hat{H}^{2} m g$ & 0.36 & 0.93 & 0.61 & 0.95 & 0.95 & 0.98 & 0.86 \\
\hline$\hat{r} g \hat{g}$ & 0.60 & 0.96 & 0.78 & 0.98 & 0.98 & 0.99 & 0.93 \\
\hline$C^{2}$ int & 0.35 & 0.00 & 0.18 & 0.00 & 0.00 & 0.01 & 0.02 \\
\hline$\hat{r g c}$ & 0.25 & 1.00 & 0.53 & 0.98 & 1.00 & 0.99 & 0.94 \\
\hline$C V g \%$ & 0.83 & 10.05 & 11.04 & 10.47 & 10.25 & 63.87 & 8.53 \\
\hline $\mathrm{CVe} \%$ & 1.73 & 10.91 & 19.26 & 9.02 & 8.77 & 23.19 & 12.61 \\
\hline \multirow[t]{2}{*}{ Overall mean } & 246.87 & 79.27 & 22.55 & 2.32 & 369.43 & 123.73 & 4896.86 \\
\hline & $\mathrm{Ca}$ & $\mathrm{Mg}$ & $\mathrm{Cu}$ & $\mathrm{Fe}$ & $\mathrm{Mn}$ & $\mathrm{Zn}$ & $\begin{array}{c}\mathrm{TA} \\
(\% \text { citric acid }) \\
\end{array}$ \\
\hline Deviance (LRT) & 11.54 & 11.92 & 12.78 & 20.36 & 29.71 & 6.50 & 5.50 \\
\hline$\sigma^{2} g$ & 0.00 & 0.01 & 0.01 & 81.20 & 29.42 & 5.86 & 0.01 \\
\hline$\sigma^{2}$ int & 0.02 & 0.00 & 0.33 & 2.69 & 3283.27 & 11.41 & 0.01 \\
\hline$\sigma^{2} e$ & 0.01 & 0.01 & 0.20 & 38.87 & 643.05 & 23.92 & 0.01 \\
\hline$\sigma^{2} p$ & 0.03 & 0.01 & 0.54 & 122.76 & 3955.75 & 41.20 & 0.03 \\
\hline$\hat{H}^{2} g$ & 0.00 & 0.51 & 0.01 & 0.66 & 0.01 & 0.14 & 0.22 \\
\hline$\hat{H}^{2} m g$ & 0.01 & 0.92 & 0.03 & 0.95 & 0.02 & 0.43 & 0.43 \\
\hline$\hat{r} g \hat{g}$ & 0.10 & 0.96 & 0.17 & 0.97 & 0.13 & 0.66 & 0.66 \\
\hline$C^{2}$ int & 0.57 & 0.01 & 0.61 & 0.02 & 0.83 & 0.28 & 0.22 \\
\hline$\hat{r g} c$ & 0.01 & 0.98 & 0.02 & 0.97 & 0.01 & 0.34 & 0.50 \\
\hline $\mathrm{CVg} \%$ & 0.56 & 3.73 & 3.54 & 13.65 & 1.83 & 6.70 & 3.69 \\
\hline $\mathrm{CVe} \%$ & 6.25 & 3.65 & 21.70 & 9.44 & 8.55 & 13.53 & 5.78 \\
\hline Overall mean & 1.85 & 2.24 & 2.09 & 66.00 & 296.69 & 36.14 & 2.05 \\
\hline
\end{tabular}

$\sigma_{g}^{2}$ (genotypic variance); $\sigma^{2}$ int (variance of the interaction of genotype $\times$ production cycle); $\sigma^{2} e$ (residual variance); $\sigma^{2} p$ (phenotypic individual variance); $\hat{H}^{2} g$ (broad sense heritability for total genotypic effects); $\hat{H}^{2} m g$ (heritability of genotypes average); $\hat{r} g \hat{g}$ (accuracy for genotype selection); $C^{2} i n t$ (coefficient of determination of the interaction of genotype $\times$ production cycle); $\hat{r} g c$ (genotypic correlation between production cycle performance); $C V g$ (genotypic variation coefficient); $C V e$ (residual variation coefficient). ${ }^{(1)}$ Total phenolic compounds expressed as mg of chlorogenic acid $100 \mathrm{~g}^{-1}$. (2) Total anthocyanins expressed as $\mathrm{mg}$ of equivalents of cyaniding-3-glucoside $100 \mathrm{~g}^{-1}$. (3) Antioxidant activity expressed as mg of equivalent trolox $100 \mathrm{~g}^{-1} \cdot{ }^{(4)}$ Deviance to $5 \%$ probability by the Chi-square test.

The morphological traits observed for raspberry genotypes during the cycles of autumn and spring presented low to moderate broad sense heritability $\left(\hat{\mathrm{H}}^{2} \mathrm{~g}\right), 12 \%$ for $\mathrm{BH}$, $46 \%$ for $\mathrm{PH}$, and $20 \%$ for DM (Table 1$)$. The FW revealed moderate heritability $\left(\hat{\mathrm{H}}^{2} \mathrm{~g}\right)$, $58 \%$. 
P.M. Marchi et al.

Phytochemical traits presented broad sense heritability of $58 \%$ for TP, $87 \%$ for AN, and $31 \%$ for AA (Table 1). In respect to the content of mineral on fruits, excepting $\mathrm{Mg}$ $(51 \%)$ and $\mathrm{Fe}(66 \%)$, considerable environmental effect was observed on the phenotypic expression. The results obtained in this study suggest that $\mathrm{BH}, \mathrm{DM}, \mathrm{AA}, \mathrm{Ca}, \mathrm{Cu}, \mathrm{Mn}, \mathrm{Zn}$, and TA were strongly influenced by the environment. The heritability average of genotypes $\left(\hat{\mathrm{H}}^{2} \mathrm{mg}\right.$ ) was higher for $\mathrm{PH}, \mathrm{FW}, \mathrm{TP}, \mathrm{AN}, \mathrm{AA}, \mathrm{Mg}$, and $\mathrm{Fe}$, with values above $85 \%$ (Table $1)$.

Only the minerals $\mathrm{Ca}, \mathrm{Cu}$, and $\mathrm{Mn}$ presented moderate to high estimates for effects of the coefficient of interaction of genotype $x$ production cycle $\left(\mathrm{C}^{2}\right.$ int $)$. Therefore, the other traits presented low interaction effects under its phenotypic expression (Table 1). For all the traits evaluated, excepting $\mathrm{Ca}$ e $\mathrm{Mn}$, moderate to high selective accuracy ( $\hat{\mathrm{r} g} \hat{\mathrm{g}})$ values were observed (Resende and Duarte, 2007).

The genotypic correlation among the two production cycles ( $\mathrm{rgc})$ was high for the traits $\mathrm{PH}, \mathrm{FW}, \mathrm{TP}, \mathrm{AN}, \mathrm{AA}, \mathrm{Mg}$, and Fe; and low for $\mathrm{BH}, \mathrm{DM}, \mathrm{Ca}, \mathrm{Cu}, \mathrm{Mn}, \mathrm{Zn}$, and TA. The genotypic variation coefficient $(\mathrm{CVg})$ observed for the trait $\mathrm{AN}$ was high (Table 1), and for the other traits low genotypic coefficient values were obtained.

\section{Best Linear Unbiased Prediction (BLUP)}

The genotype ordering, the genotypic predicted value, the estimated genetic gain by selection (\%), and the new predicted mean were obtained considering the interaction of genotype $\times$ production cycle for the morphological (Table 2), phytochemical and physicalchemical (Table 3), and fruit mineral content traits (Table 4).

Table 2. Genetic estimates for the best linear unbiased prediction (BLUP), for the broad and specific adaptability of the traits start of harvesting; plant height; pruning dry mass; and average fruit weight, measured in three raspberry cultivars during autumn and spring production cycles in Rio Grande do Sul State, Brazil.

\begin{tabular}{|c|c|c|c|c|c|c|c|c|c|c|c|c|c|}
\hline Cycle & Genotype & $\begin{array}{c}\hat{\mathrm{g}} \\
\text { Pruning dr }\end{array}$ & $\begin{array}{c}\hat{\mathbf{u}}+\hat{\mathrm{g}} \\
\mathbf{y} \text { mass }\end{array}$ & $\begin{array}{c}\text { Gain (\%) } \\
\left(\text { g plant }^{-1}\right)\end{array}$ & NM & $\hat{\mathbf{u}}+\hat{\mathrm{g}}+\hat{\mathrm{g}}_{\mathrm{em}}$ & Cycle & Genotype & $\begin{array}{l}\hat{\mathrm{g}} \\
\text { Fruit } \mathrm{v}\end{array}$ & $\begin{array}{l}\hat{\mathbf{u}}+\hat{\mathrm{g}} \\
\text { veight }\end{array}$ & Gain (\%) & NM & $\hat{\mathrm{u}}+\hat{\mathrm{g}}+\hat{\mathrm{g}}_{\mathrm{em}}$ \\
\hline \multirow{4}{*}{ Overall } & 'Heritage' & 1.54 & 24.09 & 58.55 & 24.09 & 24.78 & \multirow{4}{*}{ Overall } & 'Heritage' & 0.14 & 2.46 & 51.25 & 2.46 & 2.46 \\
\hline & 'Alemãzinha' & 0.64 & 23.19 & 41.45 & 23.64 & 23.48 & & 'Fallgold' & 0.13 & 2.45 & 48.75 & 2.46 & 2.45 \\
\hline & 'Fallgold' & -2.19 & 20.36 & 0.00 & 22.55 & 19.39 & & 'Alemãzinha' & -0.27 & 2.04 & 0.00 & 2.32 & 2.04 \\
\hline & 'Heritage' & 9.69 & 25.68 & 62.33 & 25.68 & - & & 'Heritage' & 0.15 & 2.51 & 51.42 & 2.51 & - \\
\hline \multirow[t]{3}{*}{ Autumn } & 'Alemãzinha' & 0.78 & 22.77 & 37.67 & 24.22 & - & \multirow{2}{*}{ Autumn } & 'Fallgold' & 0.13 & 2.49 & 48.58 & 2.50 & - \\
\hline & 'Fallgold' & -4.47 & 17.52 & 0.00 & 21.99 & - & & 'Alemãzinha' & -0.27 & 2.09 & 0.00 & 2.36 & - \\
\hline & 'Alemãzinha' & 1.08 & 24.19 & 54.00 & 24.19 & - & \multirow{3}{*}{ Spring } & 'Heritage' & 0.14 & 2.41 & 50.00 & 2.41 & - \\
\hline \multirow[t]{2}{*}{ Spring } & 'Heritage' & 0.77 & 23.88 & 46.00 & 24.03 & - & & 'Fallgold' & 0.13 & 2.40 & 50.00 & 2.40 & - \\
\hline & 'Fallgold' & -1.85 & 21.26 & 0.00 & 23.10 & - & & 'Alemãzinha' & -0.27 & 2.00 & 0.00 & 2.27 & - \\
\hline
\end{tabular}

*g (genotypic effect); $\hat{\mathrm{u}}+\hat{\mathrm{g}}$ (predicted genetic value); NM (new mean); $\hat{\mathrm{u}}+\hat{\mathrm{g}}+\hat{\mathrm{g}}_{\mathrm{em}}$ (predicted effects of genotype $\times$ production cycle effects).

The genotype 'Fallgold' was superior to the others for the trait SH, independent of the production cycle (Table 2). However, this trait indicates earliness, and a lower value is preferred; therefore, 'Alemãzinha' is considered the earlier genotype. This genotype also presented higher PH, but 'Heritage' was the best for DM and FW.

With respect to phytochemical and physical-chemical traits, 'Alemãzinha' was superior regarding to the AN content (Table 3), and 'Heritage' stands out for TP and AA contents. For the trait TA, genotypes with less content must to be preferred, because fruits with lower acidity are better accepted by consumers; thus, the genotype 'Alemãzinha' has greater flavor. 
Table 3. Genetic estimates for the best linear unbiased prediction (BLUP), for the broad and specific adaptability of the traits total phenolic compounds; anthocyanins; antioxidant activity; and titratable acidity, measured in three raspberry cultivars during autumn and spring production cycles in Rio Grande do Sul State, Brazil.

\begin{tabular}{|c|c|c|c|c|c|c|c|c|c|c|c|c|c|}
\hline Cycle & Genotype & $\hat{\mathbf{g}}$ & $\hat{\mathbf{u}}+\hat{\mathrm{g}}$ & Gain (\%) & NM & $\hat{\mathbf{u}}+\hat{\mathrm{g}}+\hat{\mathrm{g}}_{\mathrm{em}}$ & Cycle & Genotype & $\hat{\mathbf{g}}$ & $\hat{\mathbf{u}}+\hat{\mathrm{g}}$ & Gain (\%) & NM & $\hat{\mathbf{u}}+\hat{\mathbf{g}}+\hat{\mathrm{g}}_{\mathrm{em}}$ \\
\hline \multicolumn{7}{|c|}{ Total Phenolic Compounds ( $\mathrm{mg}$ of chlorogenic acid $100 \mathrm{~g}^{-1}$ ) } & \multicolumn{7}{|c|}{ Anthocyanins ( $\mathrm{mg}$ of equivalents of cyaniding-3-glucoside $100 \mathrm{~g}^{-1}$ ) } \\
\hline \multirow{3}{*}{ Overall } & 'Heritage' & 33.78 & 403.22 & 63.06 & 403.22 & 403.25 & \multirow{3}{*}{ Overall } & 'Alemãzinha' & 50.47 & 174.2 & 52.76 & 174.20 & 174.54 \\
\hline & 'Alemãzinha' & 5.79 & 375.23 & 36.94 & 389.22 & 403.25 & & 'Heritage' & 39.9 & 163.63 & 47.24 & 168.92 & 163.90 \\
\hline & 'Fallgold' & -39.57 & 329.86 & 0.00 & 369.43 & 329.82 & & 'Fallgold' & -90.37 & 33.36 & 0.00 & 123.73 & 32.75 \\
\hline \multirow{4}{*}{ Autumn } & 'Heritage' & 33.84 & 355.21 & 63.04 & 355.21 & - & \multirow{3}{*}{ Autumn } & 'Alemãzinha' & 45.89 & 147.71 & 51.13 & 147.71 & - \\
\hline & 'Alemãzinha' & 5.85 & 327.21 & 36.96 & 341.21 & - & & 'Heritage' & 41.86 & 143.68 & 48.87 & 145.7 & - \\
\hline & 'Fallgold' & -39.69 & 281.68 & 0.00 & 321.37 & - & & 'Fallgold' & -87.74 & 14.08 & 0.00 & 101.82 & - \\
\hline & 'Heritage' & 33.78 & 451.3 & 63.08 & 451.30 & - & \multirow{3}{*}{ Spring } & 'Alemãzinha' & 55.74 & 201.37 & 54.19 & 201.37 & - \\
\hline \multirow[t]{2}{*}{ Spring } & 'Alemãzinha' & 5.75 & 423.25 & 36.92 & 437.27 & - & & 'Heritage' & 38.48 & 184.12 & 45.81 & 192.74 & - \\
\hline & 'Fallgold' & -39.55 & 377.95 & 0.00 & 417.50 & & & 'Fallgold' & -94.21 & 51.42 & 0.00 & 145.64 & . \\
\hline Cycle & Genotype & $\hat{\mathrm{g}}$ & $\hat{\mathrm{u}}+\hat{\mathrm{g}}$ & Gain $(\%)$ & NM & $\hat{\mathrm{u}}+\hat{\mathrm{g}}+\hat{\mathrm{g}}_{\mathrm{em}}$ & Cycle & Genotype & $\hat{\mathrm{g}}$ & $\hat{\mathrm{u}}+\hat{\mathrm{g}}$ & Gain (\%) & NM & $+\hat{\mathrm{g}}_{\mathrm{em}}$ \\
\hline \multicolumn{7}{|c|}{ Antioxidant activity ( $\mathrm{mg}$ of equivalent trolox $100 \mathrm{~g}^{-1}$ ) } & \multicolumn{6}{|c|}{ Titratable acidity (\% citricacid) } & \\
\hline & 'Heritage' & 399.35 & 5296.21 & 68.16 & 5296.21 & 5308.02 & & 'Heritage' & 0.04 & 2.09 & 56.25 & 2.09 & 2.13 \\
\hline \multirow{3}{*}{ Overall } & 'Alemãzinha' & -26.31 & 4870.54 & 31.84 & 5083.38 & 4869.77 & \multirow[t]{2}{*}{ Overall } & 'Fallgold' & 0.02 & 2.08 & 43.75 & 2.08 & 2.10 \\
\hline & 'Fallgold' & -373.03 & 4523.83 & 0.00 & 4896.86 & 4512.79 & & 'Alemãzinha' & -0.06 & 2.00 & 0.00 & 2.06 & 1.94 \\
\hline & 'Heritage' & 376.86 & 3853.83 & 67.58 & 3853.83 & - & & 'Heritage' & 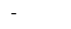 & - & - & - & - \\
\hline \multirow{3}{*}{ Autumn } & 'Alemãzinha' & -15.28 & 3461.69 & 32.42 & 3657.76 & - & \multirow{2}{*}{ Autumn } & 'Fallgold' & - & - & - & - & - \\
\hline & 'Fallgold' & -361.58 & 3115.39 & 0.00 & 3476.97 & - & & 'Alemãzinha' & 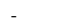 & - & & - & - \\
\hline & 'Heritage' & 445.47 & 6762.22 & 68.67 & 6762.22 & - & \multirow{3}{*}{ Spring } & 'Heritage' & 0.07 & 2.13 & 55.47 & 2.13 & - \\
\hline \multirow[t]{2}{*}{ Spring } & 'Alemãzinha' & -38.91 & 6277.84 & 31.13 & 6520.03 & - & & 'Fallgold' & 0.04 & 2.10 & 44.53 & 2.11 & - \\
\hline & 'Fallgold' & -406.56 & 5910.19 & 0.00 & 6316.75 & 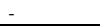 & & 'Alemãzinha' & -0.11 & 1.94 & 0.00 & 2.06 & - \\
\hline
\end{tabular}

*g (genotypic effect); $\hat{\mathrm{u}}+\hat{\mathrm{g}}$ (predicted genetic value); NM (new mean); $\hat{\mathrm{u}}+\hat{\mathrm{g}}+\hat{\mathrm{g}}_{\mathrm{em}}$ (predicted effects of genotype $\times$ production cycle effects)

The genotypes ordering defined 'Alemãzinha' as the best for several of the fruit mineral contents in both production cycles and in isolated situations (Table 4). These results showed that 'Alemãzinha' produced fruits with higher nutritive value, while 'Heritage' had lower mineral content in fruits.

Table 4. Genetic estimates for the best linear unbiased prediction (BLUP), for the broad and specific adaptability of the micro and macro minerals $\mathrm{Ca} ; \mathrm{Mg}$; $\mathrm{Cu}$; $\mathrm{Fe}$; $\mathrm{Mn}$; and $\mathrm{Zn}$, measured in three raspberry cultivars during autumn and spring production cycles in Rio Grande do Sul State, Brazil.

\begin{tabular}{|c|c|c|c|c|c|c|c|c|c|c|c|c|c|c|c|}
\hline Trait & Cycle & Genotype & $\hat{\mathrm{g}}$ & $\hat{\mathrm{u}}+\hat{\mathrm{g}}$ & Gain (\%) & NM & $\hat{\mathbf{u}}+\hat{\mathrm{g}}+\hat{\mathrm{g}}_{\mathrm{em}}$ & Trait & Cycle & Genotype & $\hat{\mathrm{g}}$ & $\hat{\mathrm{u}+\hat{\mathrm{g}}}$ & Gain (\%) & NM & $\hat{\mathbf{u}}+\hat{\mathrm{g}}+\hat{\mathrm{g}}_{\mathrm{em}}$ \\
\hline \multirow{9}{*}{$\mathrm{Mg}$} & & 'Alemãzinha' & 0.08 & 2.32 & 65.55 & 2.32 & 2.32 & \multirow{9}{*}{$\mathrm{Cu}$} & \multirow{3}{*}{ Overall } & 'Alemãzinha' & 0.01 & 2.10 & 77.78 & 2.10 & 2.52 \\
\hline & \multirow[t]{3}{*}{ Overall } & 'Fallgold' & 0.01 & 2.25 & 34.45 & 2.28 & 2.25 & & & 'Fallgold' & -0.01 & 2.08 & 22.22 & 2.09 & 1.90 \\
\hline & & 'Heritage' & -0.08 & 2.16 & 0.00 & 2.24 & 2.16 & & & 'Heritage' & -0.01 & 2.08 & 0.00 & 2.09 & 1.84 \\
\hline & & 'Alemãzinha' & 0.08 & 1.73 & 65.85 & 1.73 & - & & & 'Alemãzinha' & 0.88 & 4.52 & 77.62 & 4.52 & - \\
\hline & \multirow{3}{*}{ Autumn } & 'Fallgold' & 0.00 & 1.65 & 34.15 & 1.69 & - & & \multirow[t]{2}{*}{ Autumn } & 'Fallgold' & -0.37 & 3.63 & 22.38 & 3.90 & - \\
\hline & & 'Heritage' & -0.08 & 1.56 & 0.00 & 1.65 & - & & & 'Heritage' & -0.51 & 3.13 & 0.00 & 3.64 & - \\
\hline & & 'Alemãzinha' & 0.08 & 2.91 & 64.96 & 2.91 & - & & \multirow{4}{*}{ Spring } & 'Heritage' & 0.01 & 0.55 & 61.11 & 0.55 & - \\
\hline & \multirow[t]{3}{*}{ Spring } & 'Fallgold' & 0.01 & 2.84 & 35.04 & 2.87 & - & & & 'Fallgold' & 0.00 & 0.54 & 38.89 & 0.54 & - \\
\hline & & 'Heritage' & -0.08 & 2.75 & 0.00 & 2.83 & 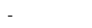 & & & 'Alemãzinha' & -0.01 & 0.52 & 0.00 & 0.53 & \\
\hline & & 'Alemãzinha' & 9.89 & 75.90 & 74.41 & 75.90 & 76.06 & & & 'Fallgold' & 0.47 & 297.16 & 54.95 & 296.69 & 253.35 \\
\hline \multirow{8}{*}{$\mathrm{Fe}$} & \multirow[t]{3}{*}{ Overall } & 'Fallgold' & -3.09 & 62.91 & 25.59 & 69.40 & 62.86 & \multirow{7}{*}{$\mathrm{Mn}$} & \multirow[t]{3}{*}{ Overall } & 'Alemãzinha' & 0.30 & 296.99 & 45.05 & 297.16 & 232.16 \\
\hline & & 'Heritage' & -6.80 & 59.20 & 0.00 & 66.00 & 59.09 & & & 'Heritage' & -0.76 & 296.93 & 0.00 & 297.07 & 313.56 \\
\hline & & 'Alemãzinha' & 10.64 & 119.65 & 73.74 & 119.65 & - & & & 'Alemãzinha' & 46.46 & 539.77 & 50.38 & 539.77 & 年 \\
\hline & \multirow[t]{3}{*}{ Autumn } & 'Fallgold' & -3.06 & 105.95 & 26.26 & 112.80 & - & & \multirow[t]{2}{*}{ Autumn } & 'Fallgold' & 45.05 & 538.36 & 49.62 & 539.06 & - \\
\hline & & 'Heritage' & -7.58 & 101.43 & 0.00 & 109.01 & - & & & 'Heritage' & -91.51 & 401.81 & 0.00 & 493.31 & - \\
\hline & & 'Alemãzinha' & 9.48 & 32.47 & 75.19 & 32.47 & - & & \multirow{3}{*}{ Spring } & 'Fallgold' & 7.82 & 107.90 & 55.09 & 107.90 & 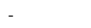 \\
\hline & \multirow[t]{3}{*}{ Spring } & 'Fallgold' & -3.22 & 19.77 & 24.81 & 26.12 & - & & & 'Heritage' & 4.93 & 105.01 & 44.91 & 106.45 & - \\
\hline & & 'Heritage' & -6.25 & 16.74 & 0.00 & 22.99 & - & & & 'Alemãzinha' & -12.76 & 87.31 & 0.00 & 100.07 & - \\
\hline \multirow{9}{*}{$\mathrm{Zn}$} & & 'Fallgold' & 1.18 & 37.34 & 56.7 & 37.33 & 38.48 & & \multirow{3}{*}{ Overall } & 'Fallgold' & 0.0009 & 1.85 & 69.23 & 1.85 & 1.92 \\
\hline & \multirow{2}{*}{ Overall } & 'Alemãzinha' & 0.62 & 36.77 & 43.3 & 37.05 & 37.37 & & & 'Alemãzinha' & -0.0001 & 1.85 & 30.77 & 1.85 & 1.84 \\
\hline & & 'Heritage' & -1.81 & 34.33 & 0.00 & 36.14 & 32.57 & & & 'Heritage' & -0.0008 & 1.85 & 0.00 & 1.85 & 1.78 \\
\hline & \multirow{4}{*}{ Autumn } & 'Fallgold' & 4.17 & 54.54 & 59.04 & 54.54 & - & & \multirow{3}{*}{ Autumn } & 'Fallgold' & 0.19 & 3.13 & 74.87 & 3.13 & - \\
\hline & & 'Alemãzinha' & 1.62 & 51.99 & 40.96 & 53.26 & - & $\mathrm{Ca}$ & & 'Alemãzinha' & -0.06 & 2.87 & 25.13 & 3.00 & - \\
\hline & & 'Heritage' & -5.79 & 44.58 & 0.00 & 50.37 & - & & & 'Heritage' & -0.13 & 2.81 & 0.00 & 2.94 & - \\
\hline & & 'Alemãzinha' & 0.85 & 22.76 & 34.62 & 22.76 & - & & \multirow{3}{*}{ Spring } & 'Alemãzinha' & 0.05 & 0.81 & 66.02 & 0.81 & - \\
\hline & \multirow[t]{2}{*}{ Spring } & 'Fallgold' & 0.50 & 22.42 & 34.10 & 22.59 & - & & & 'Heritage' & 0.00 & 0.76 & 33.98 & 0.78 & - \\
\hline & & 'Heritage' & -1.35 & 20.57 & 31.28 & 21.92 & 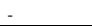 & & & 'Fallgold' & -0.05 & 0.71 & 0.00 & 0.76 & - \\
\hline
\end{tabular}

*g (genotypic effect); $\hat{\mathrm{u}}+\hat{\mathrm{g}}$ (predicted genetic value); NM (new mean); $\hat{\mathrm{u}}+\hat{\mathrm{g}}+\hat{\mathrm{g}}_{\mathrm{em}}$ (predicted effects of genotype $\times$ production cycle effects). 
P.M. Marchi et al.

8

The new predicted mean defines that the clones should produce at a rate similar to commercial crops (Borges et al., 2010). If the genotypic predicted estimated value $(\mathrm{g}+\mathrm{u})$ is similar to the new mean, this prediction is probably real (Carvalho et al., 2017). In our study, the predicted values were similar to the new mean, which means that these estimates are reliable and consistent.

\section{Multivariate profile classification of traits heritability}

The multivariate approach to define inheritable profiles was developed through average Euclidian distance of the broad sense heritability, for the traits BH, DM, PH, FW, TP, AN, Ca, Mn, $\mathrm{Cu}, \mathrm{Zn}, \mathrm{Mg}$, and Fe. These distances were submitted to the UPGMA clustering method to build a dendrogram (Figure 1). The matrix distances average was a criterion to classify the clusters $(\mu: 0.1453)$.

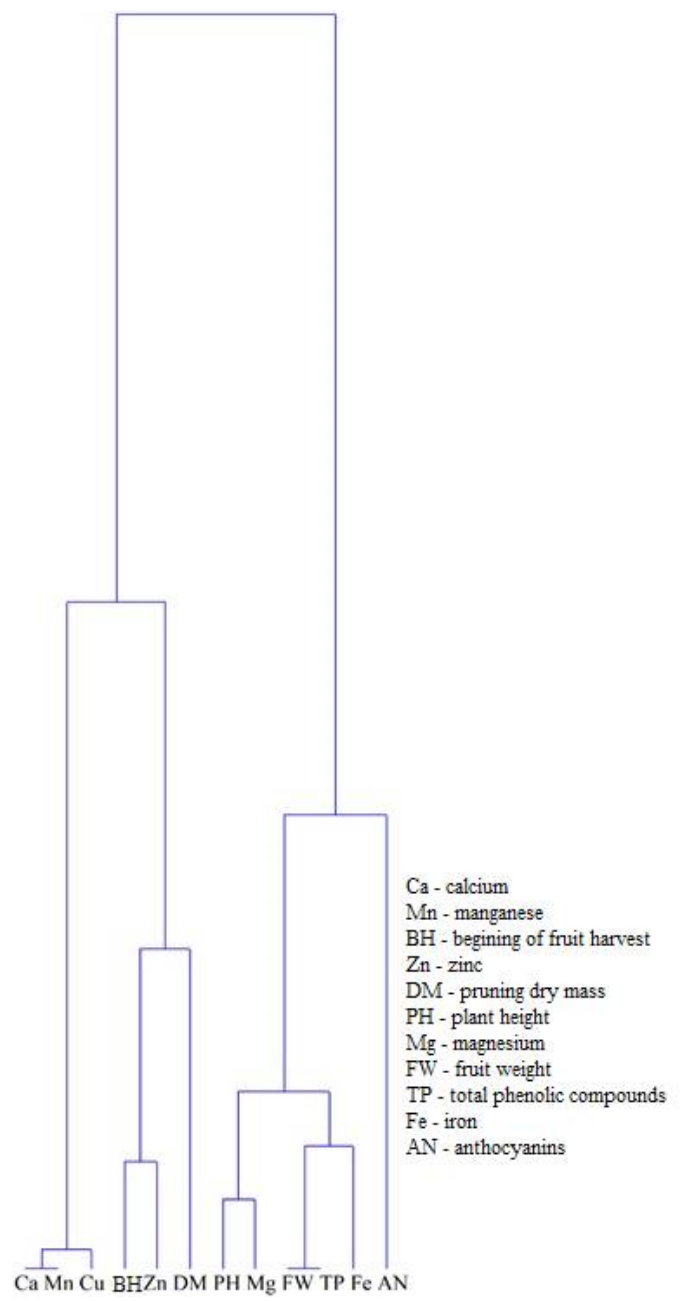

Figure 1. Dendrogram of the three raspberry cultivars, 'Alemãzinha', 'Heritage', and 'Fallgold', with genetic dissimilarity obtained through broad sense heritability for the traits $\mathrm{Ca}, \mathrm{Mn}, \mathrm{Cu}, \mathrm{BH}, \mathrm{Zn}, \mathrm{DM}, \mathrm{PH}, \mathrm{Mg}, \mathrm{FW}, \mathrm{TP}$, Fe and AN, using the mean Euclidean distance, and the UPGMA clustering method. 
The profile I $\left(\hat{\mathrm{H}}^{2}: \mathrm{Ca}=0.00 ; \hat{\mathrm{H}}^{2}: \mathrm{Mn}=0.01 ;\right.$ e $\left.\hat{\mathrm{H}}^{2}: \mathrm{Cu}=0.01\right)$ grouped the fruit mineral contents of $\mathrm{Ca}, \mathrm{Mn}$, and $\mathrm{Cu}$; while the profile II $\left(\hat{\mathrm{H}}^{2}: \mathrm{BH}=0.12 ; \mathrm{e} \hat{\mathrm{H}}^{2}: \mathrm{Zn}=0.14\right)$ included SH and $\mathrm{Zn}$ contents; and the profile III $\left(\hat{\mathrm{H}}^{2}: \mathrm{DM}=0.20\right)$ was composed only by $\mathrm{DM}$. The profile IV $\left(\hat{\mathrm{H}}^{2}: \mathrm{PH}=0.46 ; \hat{\mathrm{H}}^{2}: \mathrm{Mg}=0.51 ; \hat{\mathrm{H}}^{2}: \mathrm{FW}=0.57 ; \hat{\mathrm{H}}^{2}: \mathrm{TP}=0.58 ;\right.$ and $\hat{\mathrm{H}}^{2}$ : $\mathrm{Fe}=0.66)$ joined $\mathrm{PH}, \mathrm{FW}, \mathrm{Mg}, \mathrm{Fe}$, and $\mathrm{TP}$; and the profile $V\left(\hat{\mathrm{H}}^{2}: \mathrm{AN}=0.87\right)$ is represented by AN.

\section{DISCUSSION}

Broad sense heritability is a parameter that expresses the proportion of the phenotypic variance that can be attributed to variance of all genotypic effects - additivity, dominance and epistasis (Visscher et al., 2008). The PH is a trait related with plant vigor, and low narrow sense heritability for this trait in raspberries was observed by Bautista et al. (2017) $\left(\hat{\mathrm{h}}^{2}=0.18\right)$. The narrow sense heritability contains the variation in additive genetic effects, this explain the reason for lower values than broad sense heritability demonstrated in this study $\left(\hat{\mathrm{H}}^{2} \mathrm{~g}=46 \%\right)$.

The fruit size, expressed by its weight (FW), is a relevant commercial trait as yield and quality component (Bautista et al., 2017; Stephens et al., 2012a). This study revealed that $58 \%$ of FW expression is due to genetic effects, similarly to Bautista et al. (2017) and González (2016), who observed moderate narrow sense heritability, $\hat{h}^{2}=0.48$ and $\hat{h}^{2}=0.52$, respectively, for this trait in raspberry. Raspberry yield is highly positively correlated with fruit size, and this is probably the easiest component for which breeders can select, suggesting that easiest gain in total yield could come from breeders selecting for increase berry weight (Stephens et al., 2012b).

Although each program has specific goals, good yields and fruit quality are common goals that breeders have identified as primary focus (Bautista et al., 2017). More recently, successful genotypes have to present compounds that are associated with improved human health benefits, such as phenolic compounds, antioxidant activity, and anthocyanins (Stephens et al., 2012a). In this regard, this study found moderate to high heritability values for the traits TP, AA, AN, Mg and Fe (Table 1).

The fact that the genotypic variance $\left(\sigma^{2} g\right)$ was higher than residual variance $\left(\sigma^{2} \mathrm{e}\right)$ for the traits FW, TP, AN, and Fe, represents the possibility of gains by selection, mainly for AN, which presented less than $20 \%$ of its phenotypic variance $\left(\sigma^{2} p\right)$ due to residual effects $\left(\sigma^{2}\right.$ e) (Table 1$)$. Anthocyanins are powerful antioxidants found in relatively high concentrations in raspberry, and may contribute to its high health properties (Stephens et al., 2012a). Similarly to this study, some other works revealed that these compounds are genetically inherited and have high heritability in raspberry, which indicate potential to breed fruits with increased anthocyanin content (Connor et al., 2005; Dossett et al., 2008; Stephens et al., 2009; Stephens et al., 2012a). According to Stephens et al. (2009) and Connor et al. (2005), the narrow sense heritability is moderate for phenolic compounds and antioxidant activity.

Genetic advance achieved through out selection in a raspberry breeding program depends on the total phenotypic variation into the conducted population, heritability of an interesting trait and the selection pressure (Bautista et al., 2017). Our results about the heritability $\left(\hat{\mathrm{h}}^{2} \mathrm{~g}\right)$ of $\mathrm{PH}, \mathrm{FW}, \mathrm{TP}, \mathrm{AN}, \mathrm{Mg}$, and Fe suggest that reasonably rapid progress through breeding can be expected for these traits. 
The accuracy of heritability estimate depends on its sample error. A larger response to selection can be achieved if the accuracy values are high, but the prediction of breeding values accuracy remains a heritability function (Visscher et al., 2008). The selective accuracy ( $\hat{\mathrm{r} g} \hat{g})$ represents the correlation among the estimated genotypic values and the measurements. For all the traits evaluated, excepting $\mathrm{Ca}$ e $\mathrm{Mn}$, moderate to high accuracy values were observed in this study, due to the fact that environmental effects biases were minimized by the considerable observations number.

The coefficient of determination of the interaction effects of genotype $\times$ production cycle $\left(\mathrm{C}^{2}\right.$ int $)$ quantify the fraction from total variance (phenotypic) that is due to differential effects of the genotype $\times$ production cycle interaction (Sturion and Resende, 2005). Only $\mathrm{Ca}, \mathrm{Cu}$, and $\mathrm{Mn}$ presented moderate to high estimates. Therefore, the other traits presented low interaction effects under its phenotypic expression (Table 1).

The genotypic correlation among the two production cycles (r̂gc) was high for the traits $\mathrm{PH}, \mathrm{FW}, \mathrm{TP}, \mathrm{AN}, \mathrm{AA}, \mathrm{Mg}$, and Fe, which means that these effects are characterized as simple interactions. The low correlation ( $\mathrm{rgc}$ ) observed for $\mathrm{BH}, \mathrm{DM}, \mathrm{Ca}, \mathrm{Cu}, \mathrm{Mn}, \mathrm{Zn}$, and TA indicates that the effects are due to a complex interaction, resulting in low phenotypic stability of the genotypes (Pupin et al., 2015).

The genotypic variation coefficient $(\mathrm{CVg})$ observed for the trait AN was high, indicating higher genetic variability for the genotypes studied (Table 1). Low genotypic coefficient values obtained for the other traits indicated significant role of the environment on their expression. Fruit mineral contents and TA, for example, are influenced by weather and soil conditions. However, the genotypic variance coefficient is not a correct measure to know the heritable variation, and should be considered together with heritability estimates (Akšić et al., 2011).

The multivariate analysis defined five inheritable profiles for the raspberry cultivars. The profile I grouped the fruit mineral contents of $\mathrm{Ca}, \mathrm{Mn}$, and $\mathrm{Cu}$; the profile II included SH and Zn contents; and the profile III was composed only by DM. These three first clusters have in common low broad sense heritability, which means low genetic variability available for selection. The profile $I V$ joined $\mathrm{PH}, \mathrm{FW}, \mathrm{Mg}, \mathrm{Fe}$, and $\mathrm{TP}$, the profile $V$ is represented by AN. An inheritance type characterized as high heritability was observed only for profile $V$; however, some advances in breeding can also be obtained for the traits of the profile $I V$.

According to Akšić et al. (2011), the future of raspberry production will be largely dependent on breeding efforts, and the solution to current and future problems will be genetic in nature, since the majority of quantitative traits, such as yield components and some fruit quality attributes are under multigenic control and are inherited additively with a significant genetic interaction. Therefore, this study elucidated genetic parameters and variance components of three primocane-fruiting raspberry genotypes, during the autumn and spring production cycles, in southern Brazil, which contributes to improvement of knowledge, better understanding and advance of the crop and its breeding.

In conclusion, raspberry fruits anthocyanins content can be improved through selection, based on its genetic parameters. PH, FW, TP, Mg, and Fe presented moderate broad sense heritability, and the traits $\mathrm{BH}, \mathrm{DM}, \mathrm{AA}, \mathrm{Ca}, \mathrm{Cu}, \mathrm{Mn}, \mathrm{Zn}$, and AT were strongly influenced by effects of production cycles. Greater genetic variance contribution in the interaction of genotype $\times$ production cycle was observed for $\mathrm{PH}, \mathrm{FW}, \mathrm{TP}, \mathrm{AN}, \mathrm{AA}, \mathrm{Mg}$, and Fe. The genotype 'Alemãzinha' presented superiority for $\mathrm{BH}, \mathrm{PH}, \mathrm{AN}, \mathrm{AT}$, and several minerals. The multivariate approach defined five inheritance profiles for raspberry cultivars. 
The genetic estimates and prediction are reliable, which means these results can be used in future quantitative genetic studies and selection strategies of raspberry breeding programs.

\section{ACKNOWLEDGMENTS}

The authors would like to thank to Embrapa Temperate Agriculture, CAPES (Coordination for the Improvement of Higher Level Personnel) and the National Council for Scientific and Technological development (CNPq) for funding support and scholarships.

\section{REFERENCES}

Akšić MF, Radović A, Milivojević J, Nikolić M, et al. (2011). Genetic parameters of yield components and pomologic properties in raspberry seedlings. Genetika. 43: 667-674.

Alvares CA, Stape JL, Sentelhas PC, Gonçalves JLM, et al. (2014). Köppen's climate classification map for Brazil. Meteorol. Z. 22: 711-728.

Bautista AH, Ortiz RL, Zavala JJG, Servia JLC, et al. (2017). Breeding potential of raspberry primocane selections based on their combining abilities. Can. J. Plant Sci. 98: 28-37.

Borges V, Ferreira PV, Soares L, Santos GM, et al. (2010). Sweet potato clone selection by REML/BLUP procedure. Acta Sci. Agron. 32: 643-649.

Brand-Williams W, Cuvelier ME and Berset C (1995). Use of a free radical method to evaluate antioxidant activity. $L W T$ - Food Sci. Technol. 28: 25-30.

Carvalho IR (2018). Genetic breeding and biometry applied to biofortification of maize grains Doctoral thesis. Federal University of Pelotas, Pelotas. Available at [http://repositorio.ufpel.edu.br:8080/bitstream/prefix/3812/1/Tese\%20Ivan\%20Ricardo\%2005.03\%20Ajustada\%2 e\%20correta.pdf].

Carvalho IR, Pelegrini AJ, Szareski VJ, Ferrari M, et al. (2017). Diallel and prediction (REML/BLUP) for yield componentes in intervarietal maize hybrids. Genet. Mol. Res. 16: 1-12.

Connor AM, Stephens MJ, Hall HK and Alspach PA (2005). Variation and heritabilities of antioxidant activity and total phenolic content estimated from a red raspberry factorial experiment. J. Am. Soc. Hortic. Sci. 130: 403-411.

Cruz CD (2013). Genes- a software package for analysis in experimental statistics and quantitative genetics. Acta Sci. Agron. 35: 271-276.

Dosset M, Lee J and Finn CE (2008). Inheritance of phonological, vegetative, and fruit chemistry traits in black raspberry. J. Am. Soc. Hortic. Sci. 133: 408-417.

Fuleki T and Francis F (1968). Quantitative methods for anthocyanins. J. Food Sci. 33: 72-77.

Gambardella M, Bañados P, Sánchez S, Grez J, et al. (2016). New raspberry cultivars for Chile: first releases from the local breeding program. Acta Hort. 1117: 19-23.

González MD (2016). Heritability of primocane-yield components in red raspberry. Acta Hort. 1133: 75-80.

Jennings SN, Graham J, Ferguson L and Young V (2016). New developments in raspberry breeding in Scotland. Acta Hort. 1133: 23-28.

Milivojevic JM, Nikoli MD, Maksimovic JJD and Radivojevic DD (2011). Generative and fruit quality characteristics of primocane fruiting red raspberry cultivars. Turk J. Agric. For. 35: 289-296.

Moore PP and Hoashi-Erhardt W (2016). Raspberry breeding at Washington State University. Acta Hort. 1133: 45-48.

Orzel A, Simlat M and Danek J (2016). Directions in raspberry and blackberry breeding program conducted in NIWA Berry Breeding Ltd., Brzezna, Poland. Acta Hort. 1133: 29-34.

Palonen P, Pinomaa A and Tommila T (2017). The influence of high tunnel on yield and berry quality in three floricane raspberry cultivars. Sci. Hortic. 214: 180-186.

Pritts M (2008). Primocane-fruiting raspberry production. HortScience. 43: 1640-1641.

Pupin S, Santos AVA, Zaruma DUG, Miranda AC, et al. (2015). Productivity, stability and adaptability in open pollination progenies of Eucalyptus urophylla S.T. Blake. Sci. For. 43: 127-134.

Resende MDV (2007). Software SELEGEN-REML/BLUP: Statistics system and computed genetic selection by mixed linear models. Embrapa Florestas, Colombo, PR.

Resende MDV and Duarte JB (2007). Precision and quality control in variety trials. Pesq. Agropec. Trop. 37: 182-194.

Skrovankova S, Sumczynski D, Mlcek J, Jurikova T, et al. (2015). Bioactive compounds and antioxidante activity in diferent types of berries. Int. J. Mol. Sci. 16: 24673-24706.

Spilke J, Phiepho HP and Hu X (2005). Analysis of unbalanced data by mixed linear models using the Mixed Procedure of the SAS System. J. Agron. Crop Sci. 191: 47-54.

Stephens MJ, Alspach PA, Beatson RA, Winefield C, et al. (2012a). Genetic parameters and development of a selection index for breeding red raspberries for processing. J. Am. Soc. Hortic. Sci. 137: 236-242. 
P.M. Marchi et al.

Stephens MJ, Alspach PA, Beatson RA, Winefield C, et al. (2012b). Genetic parameters and breeding for yield in red raspberry. J. Am. Soc. Hortic. Sci. 137: 229-235.

Stephens MJ, Scalzo J, Alspach PA, Beatson RA, et al. (2009). Genetic variation and covariation of yield and phytochemical traits in a red raspberry factorial study. J. Am. Soc. Hortic. Sci. 134: 445-452.

Sturion JA and de Resende MDV (2005). Selection of erva-mate (Ilex paraguariensis St. Hil.) progenies for leafweight productivity, temporal stability andadaptability. Pesqui. Florest. Bras. 50: 37-51.

Swain T and Hillis WT (1959). The phenolic constituints of Prunus domestica. J. Sci. Food Agric. 10: 135-144.

Tedesco JM, Gianelo C, Carlos AB, Bohnen H, et al. (1995). Analisys of soil, plants and other materials. 2nd ed., Boletim técnico n. 5. Porto Alegre, RS.

Visscher PM, Hill WG and Wray NR (2008). Heritability in the genomics era - concepts and misconceptions. Nat. Rev. Genet. 9: 255-266. 